by Yanjun Shang ${ }^{l, *}$, Zhifa Yang ${ }^{l}$, Wantong $\mathrm{He}^{l}$, Lihui Li $^{l}$, Peng Yang ${ }^{l}$, Qiaohui $\mathrm{Luo}^{2}$, Chenxiao Tao ${ }^{2}$, Tianbin $\mathrm{Li}^{3}$

\title{
Mining induced collapse in 1997 and seismic records at Changyu, SE China
}

\author{
${ }^{1}$ Key Laboratory of Shale Gas and Geoengineering, Institute of Geology and Geophysics, Chinese Academy of Sciences, \\ Beijing 100029, China.*E-mail: jun94@mail.igcas.ac.cn. \\ ${ }^{2}$ Changyudongtian Tourism Industrial co., LTD, Wenzhou 317502, Zhejiang, China. \\ ${ }^{3}$ SKLGP, Chengdu University of Technology, Chengdu 610059, China.
}

(Received 14/7/2015; Accepted 12/02/2016)

DOI:10.18814/epiiugs/2016/v39i4/103890

Quarry induced collapse, an issue of particular concern in the mining industry, is a typical form of manmade disaster. Identification of the morphological characteristics of such collapses is commonly based on seismic records but comprehensive studies regarding the mechanism and energy conversion mode utilizing the seismic record is seldom undertaken. A huge collapse event at the Biyutan mining cavern at Changyu Dongtian in Wenling city, China, lasting for about 20 seconds, was observed on August 11, 1997. After the collapse, nearly 11 million $\mathrm{m}^{3}$ of rock blocks were left on the floor. By conducting a field survey on engineering geology, retrospectively analyzing the collapsing process through interviewing local residents, referring to related documents, and identifying the seismic records obtained from 3 surrounding seismic stations, it was established the roof collapse at the Biyutan cavern, excavated in massive tuff, was due to over excavation of several pillars, which substantially affected the stress field in cavern roof giving rise to a local failure of the roof that gradually developing into a widespread failure in an area EW $800 m$ long, SN 460m wide. During the collapse, outbursts of water and air shock waves result in loss of life and property within a distance of $150 \mathrm{~m}$ from the mine opening. This reminds us that reasonable allocation of sufficiently strong safety pillars and installation of monitoring system are absolutely essential in quarrying operations to avoid overall failure and ensure the safety of the people nearby.

\section{Introduction}

The "room and pillar" mining method leaves caverns that generally disturb the balance of stress in rock mass (Merad et al., 2004). If the rock mass is subjected to intolerable stress variations, such as great tensile or compressive stress concentrations (Hatzor et al., 2002), the caverns may collapse producing seismic waves and in some cases reactivate inactive faults causing minor mining induced or collapse earthquakes (Alvarez-Garcia et al., 2013). A critical in-situ stress field is not the necessary prerequisite to the occurrence of a collapse earthquake. Unlike a natural earthquake, it does not indicate a change of regional in-situ stress, nor is it closely related to regional seismic activity and does not serve as an evidence of the existence of active faults (Hu et al., 1998).

To distinguish between tectonic earthquakes, explosion induced earthquakes and collapse earthquakes, the Datong seismic station (DSS, 1974) in north China collected and analyzed seismic records over a period of one and a half years, and characterized the collapse earthquake as follows: (1) the first motion direction at the vertical record chart is downward, indicating a compression wave; (2) both the longitudinal wave $P$ and transverse wave $S$, especially the former, have a period greater than, and much purer waveform than, tectonic or explosion induced earthquakes because the latter two have more complex secondary waves; (3) The seismic wave of a collapse induced earthquake has a greater attenuation than tectonic or explosion induced earthquakes. Zhao et al. (1995) distinguished the three types of earthquakes using a telemetric seismic network in the Beijing area. Zhang et al. (2013) investigated the corner frequencies of tectonic and collapse earthquakes at the Three Gorges Reservoir and found that an obvious surface wave was observed in collapse earthquakes and that the corner frequency of $P$ and $S$ waves from tectonic earthquakes is significantly greater than those of collapse earthquakes. They believed this to be generally applicable and that it can be used as an index for identifying different earthquake types. The surface wave, which is hardly seen in tectonic earthquakes, can be clearly observed in the seismic record of both collapse and explosion induced earthquakes. Therefore, a seismic record with a strong surface wave could indicate either a collapse or explosion induced earthquake (Li and Dong, 2001).

Based on the seismic records of 7 tectonic earthquakes and 4 collapse earthquakes registered by a seismic network at south-central Shandong Province, Lin et al. (1990) studied the earth's internal structure and the focal features of earthquakes through the attenuation curves of phase and amplitude versus distance, as well as the travel 
time curves of earthquakes. Di et al. (2009) compared seismic records of 50 collapse earthquakes from a digital seismic network at Shan'anxi Province, and analyzed the basic characteristics of collapse earthquakes in Yulin City in terms of their waveform, occurrence time, and position. At Datong coal mine where the coal seam roof is strong, the area of individual caverns totals tens of thousands square meters. If these caverns collapse, the collapsed area would be as large as 20,000 to $40,000 \mathrm{~m}^{2}$ or, in some cases, 80,000 to $130,000 \mathrm{~m}^{2}$, sufficient to cause huge collapse earthquakes (He et al., 1997). Before impoundment of Three Gorges Reservoir, the seismic activity in that area was weak but, subsequently, the causes have been complicated, including natural earthquakes, explosion earthquakes in mining (Yang et al., 1993; Hu et al., 1998), earthquakes occurring after intense rainfall, and collapse earthquakes caused by subsidence of overburden (Gu, 1982).

Farahani and Zare (2014) compared $H / V$ amplification functions for the three kinds of seismic sources and demonstrated higher ratios in quarry blasts due to the importance of surface waves from shallow quarry blasts than for earthquakes or microtremors.

The study of the seismic record, analysis of the mechanism of collapse and consideration of the hazard from the shock wave is important from the perspective of engineering geology and rock mechanics. This permits systematic consideration of the kinetic energy revealed by the seismic record and field investigation. Results are of great significance.

The mine voids at Changyu Dongtian (which are referred to as "cavern groups" in Chinese) are within Wenling City, Zhejiang province. These caverns occupying a total area of $1.55 \mathrm{~km}^{2}$ have existed for some 1500 years, and still serve as an important mining complex.

The extractive operation in Changyu Dongtian began over 1500 years ago (Chinese Southern and Northern dynasties 420-589 A.D.) and, during the Song Dynasty, a primitive mining industry was began. It was not until the morning of August 11, 1997 that a catastrophic roof collapse occurred in the Biyutan cavern group that caused mining operations to cease. Before that event, the cavern group consisted of 1314 single caverns and occupied an area of $318,000 \mathrm{~m}^{2}$. According to research, the stone excavated from Changyu Dongtian were originally used for building tombs. During Southern Song Dynasty, the authority constructed weirs and dams along the seashore and river bank to meet in the great demand for stone which significantly boosted the development of the mining industry in Wenling.

When it came to the Ming Dynasty, to defend against the invasion of foreign enemies, the local leader, He Tang (1326-1395A.D.) had more than 70 cities built along the coast of East China Sea, which further expanded the demand for stone from Changyu. During the late Ming Dynasty and early Qing Dynasty, some caverns were used by local people as a religious venue and these were also often visited by scholar-bureaucrats. Meanwhile, a sculpture industry also flourished in this region (Chen and Zhu, 2012).

In 1997 that the Changyu Dongtian area became a scenic spot because it is an integral part of the Yandang Mountain World Geopark. About 1300 caverns, belonging to 28 cavern groups, were identified in Changyu Dongtian (Wenling Tourism Management Bureau, 2005). The Biyutan cavern group is one of the 28 groups, which is separated from the northern Shuiyundong cavern group by an east-west striking stone transport road (STR) (now being transformed into a passage to the caverns) (Fig.1). At 7:01 am on August 11, 1997, during the tunneling process, the Biyutan cavern group collapsed, leaving
11 million $\mathrm{m}^{3}$ rock blocks on the floor. We undertook field investigations tracing the collapse process, analyzed the seismic records, studied the mechanism of collapse and proposed advice to prevent similar disasters from occurring.

\section{Environmental conditions}

\section{Climate}

Changyu Dongtian has a subtropical maritime monsoon climate. The extremely low and high temperatures are $6.6^{\circ} \mathrm{C}$ and $40.6^{\circ} \mathrm{C}$ (July 2004), respectively, and the annual average temperature is $17.3^{\circ} \mathrm{C}$. The mean annual precipitation is $1660 \mathrm{~mm}$, and the average annual evaporation is $1270.2 \mathrm{~mm}$. There are two obvious rainy seasons: the "plum rain" from May to June and typhoon and tropical storm affected rainy season from July to September. Typhoons and heavy rains often result in geohazards such as landslides and rock avalanches.

\section{Landforms}

This district is located in a coastal hilly and plain region of Zhejiang Province consisting of denudation hills and pluvial landform areas. The GPS coordinates of the collapsed area are E $121^{\circ} 25^{\prime} 54.33^{\prime \prime}$ and N $28^{\circ} 26^{\prime} 8.64 "$, and the elevation of the platform and the top of the mountain above sea level is $50 \mathrm{~m} \sim 271 \mathrm{~m}$. The fluctuation of the hilly topography is quite large with the greatest height difference from $160 \mathrm{~m} \sim 220 \mathrm{~m}$. The slope gradient is generally $30^{\circ} \sim 40^{\circ}$, and at some places reaches $40^{\circ} \sim 60^{\circ}$ (Fig.1).

\section{Strata and structures}

This district is located in the Mesozoic era active volcanic zone of the coastal area of east Zhejiang, and also the middle of Wenhuang plain. The geological characteristics are controlled by the JinqiaoChangyu caldera which was formed in late Jurassic epoch. These strata of the south China stratigraphic region II, belong to the Upper Jurassic Zhuji formation $\left(\mathrm{J}_{3} \mathrm{z}\right)$, which consists of acidic welded tuff with sedimentary interlayers, a type of subvolcanic rocks near volcano channels. Quaternary residual and talus deposits $\left(\mathrm{Q}_{4}\right)$ are observed in the valleys and on the slope surfaces (Fig.2). At some locations of the mountain, green grey diabase dykes with stable attitude and thickness are found (Fig.3).

The collapse area is located on the south side of Huangjian Mountain. The south boundary of the collapse area is an erect steep cliff (stretching EW as in Fig.1b, Fig.4). Also, a large gully called Shichuangou, with a strike of $38^{\circ}$ along a normal fault striking NE, can be seen at left top in Fig.4. This lies to the east of the collapsed area (Fig.1b).

By microscopic observation in thin section of the rock samples collected in site, it was found that the petrology in the collapse area is mainly purple grey massive rhyolitic and trachytic rock with a welded tuff texture and a rhyotaxitic structure. Slight development of rigid breccia and compressed plastic fragments are observed occasionally (Fig.3d).

In the massive tuff, a moderately thick ( $1.5 \mathrm{~m} \sim 2.9 \mathrm{~m}$ thick) gently dip diabase dyke (attitude $357^{\circ} \angle 75^{\circ}$ ) is observed. A clear smooth boundary separates the tuff and the dyke, therefore we suggest that the dyke formed by intrusion along extensive joints. In addition, the authors carried out a general chemical analysis of samples collected 


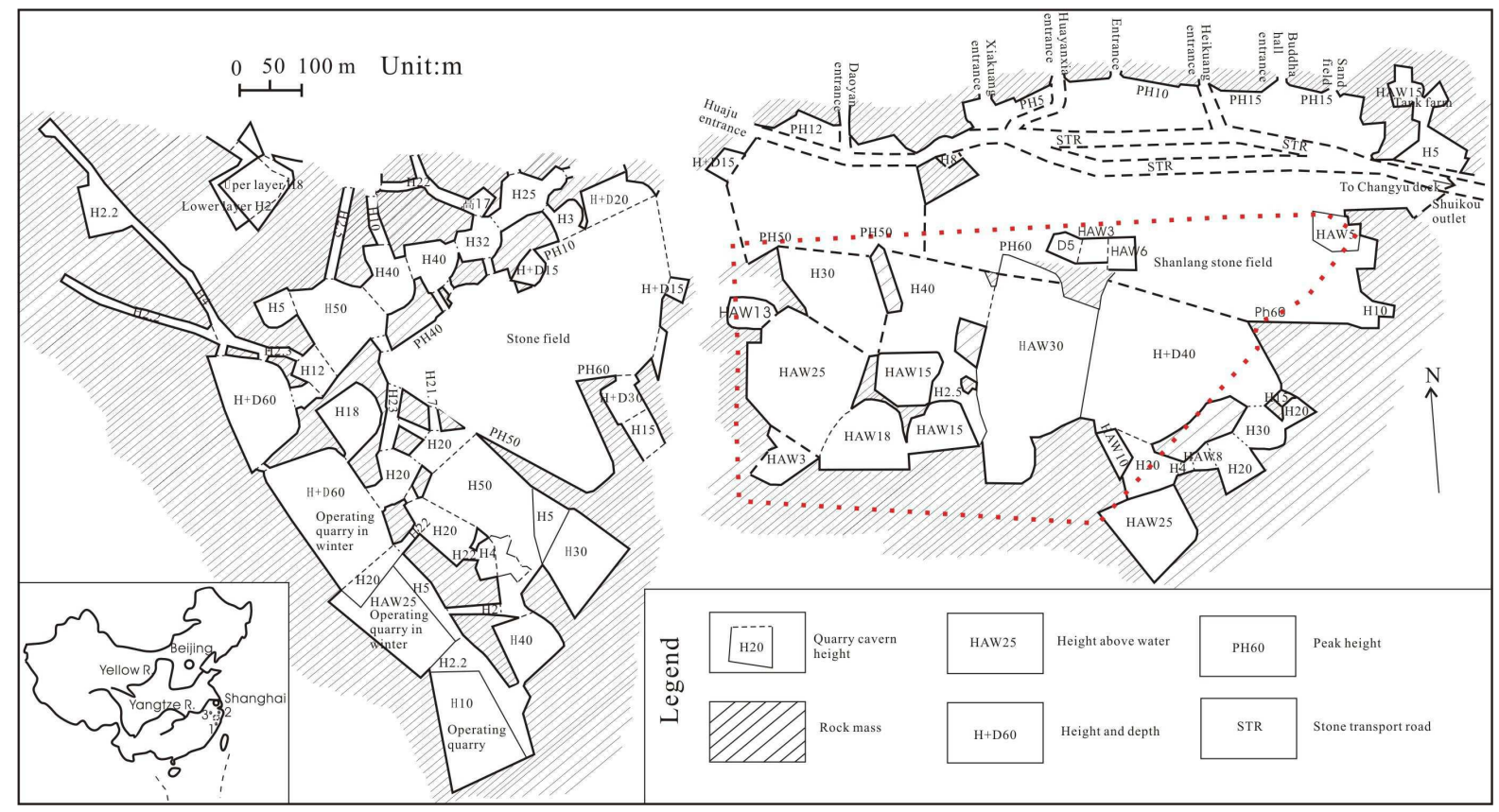

Figure.1a. The quarry cavern group and collapsed area. In the location map left bottom, 1, 2 and 3 represent Wenling, Ningbo and Xin'anjiang Seismic Station sites. The red line of dashes primarily circles the collapse boundary.

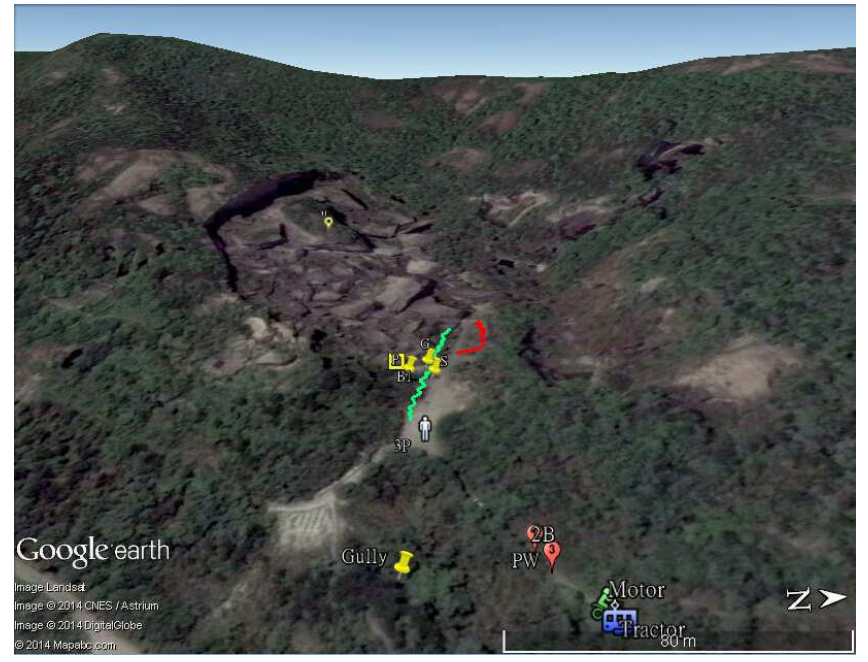

Fig.1b. Birds eye view of the collapsed area (Google Earth, 2014). G-gate (outlet), S-stop park, 3P-three walking people, GullyShichuan Gully, PW-one-story power generation building, $2 B$-two three-story buildings, Motor-Honda heavy motorcycle. Red lineroad.

from dark green gray dolerite dykes (CY-1, CY-1P). The results show that the rock samples are rich in $\mathrm{SiO}_{2}, \mathrm{Al}_{2} \mathrm{O}_{3}, \mathrm{Fe}_{2} \mathrm{O}_{3}$ and $\mathrm{MgO}$ (Table 1).

\section{Structural geology}

Changyu Dongtian is located in south China fold system (first order tectonic $\mathrm{I}_{2}$ ), southeast Zhejiang fold belt (secondary structure $\mathrm{II}_{3}$ ), Wenzhou-Linhai depression $\left(\mathrm{III}_{8}\right)$, Huangyan-Xiangshan fault depression $\left(\mathrm{IV}_{11}\right)$ (ZGMB, 1989). The Taishun-Huangyan Fault striking NE passes borders this region on the northwest. The dominant strikes of regional tectonic framework are NE and NW (Fig.2). The regional tectonics are simple and large scale faults are seldom seen.
Therefore, the discontinuities are mainly joints and fissures. The compression-shear joints form several conjugate joint systems. The predominant strike directions of joints are $\mathrm{N}$ and SSW, while the secondary dominant direction strikes SE (Fig.1b, Fig.2).

In terms of current tectonic movements, the characteristic period of the seismic response spectrum is $0.35 \mathrm{~s}$, and the seismic peak acceleration is not more than $0.05 \mathrm{~g}$ (National Standard of PRC, GB50011-2010). Earthquakes are limited to magnitude Ms 4.0, with the seismic intensity less than six degree (National Standard of PRC, GB18306-2001). Therefore, the regional crust is generally stable.

Tectonic discontinuities are few and scattered with high dip angles. The structural planes are uneven, mostly formed by shearing, but in some locations the tensio-shear faults are also observed, e.g. the fault exposed in Shuiyun cavern wall which has an attitude of $20^{\circ} \angle 75^{\circ}$, and the width of the opening is $5 \mathrm{~cm} \sim 10 \mathrm{~cm}$. The 15 sets of joints measured at that site strike EW overall, consistent with the strikes of the rear cliff and side peaks (Fig.5).

\section{Physical and mechanical parameters}

To evaluate the engineering geological conditions of the collapse site, we sampled representative massive tuffs and layered diabases, and carried out laboratory tests on the intact rock samples. The results are given in Table 2. It can be seen that the density of tuff is smaller, as are the compressive and tensile strengths of the tuffs, but the diabase has a much greater density and elastic modulus than the tuff. Both can be classified as hard rocks that have strong resistance to weathering and water softening.

\section{Evaluation of the engineering geological conditions}

The NE strike faults control boundary conditions of different zones in this area and the volcanic vent dominates the south side of the Changyu Dongtian. Some small scale veins are parallel with faults 
Table 1 Results of general chemical analysis of the diabase (weight percentage \%)

\begin{tabular}{|c|c|c|c|c|c|c|c|c|c|c|c|c|}
\hline Sample & $\mathrm{SiO}_{2}$ & $\mathrm{TiO}_{2}$ & $\mathrm{Al}_{2} \mathrm{O}_{3}$ & $\mathrm{TFe}_{2} \mathrm{O}_{3}$ & $\mathrm{MnO}$ & $\mathrm{MgO}$ & $\mathrm{CaO}$ & $\mathrm{Na}_{2} \mathrm{O}$ & $\mathrm{K}_{2} \mathrm{O}$ & $\mathrm{P}_{2} \mathrm{O}_{5}$ & LOI & Total \\
\hline $\mathrm{CY}-1$ & 48.26 & 1.01 & 17.05 & 9.52 & 0.18 & 5.83 & 4.79 & 4.38 & 3.11 & 0.28 & 5.69 & 100.10 \\
\hline \multirow[t]{2}{*}{ CY-1P } & 48.17 & 1.02 & 17.01 & 9.55 & 0.18 & 5.86 & 4.81 & 4.35 & 3.09 & 0.28 & 5.73 & 100.05 \\
\hline & $\begin{array}{l}\mathrm{FeO} \\
(\%)\end{array}$ & $\begin{array}{c}\mathrm{Ba} \\
(\mathrm{ppm})\end{array}$ & $\begin{array}{c}\mathrm{Cr} \\
(\mathrm{ppm})\end{array}$ & $\begin{array}{c}\mathrm{Ni} \\
(\mathrm{ppm})\end{array}$ & $\begin{array}{c}\mathrm{Sr} \\
(\mathrm{ppm})\end{array}$ & $\begin{array}{c}\mathrm{V} \\
(\mathrm{ppm})\end{array}$ & $\begin{array}{c}\mathrm{Zr} \\
(\mathrm{ppm})\end{array}$ & & & & & \\
\hline CY-1 & 4.89 & 760 & 18 & 12 & 1433 & 215 & 91 & & & & & \\
\hline CY-1P & 4.78 & 742 & 15 & 14 & 1426 & 221 & 91 & & & & & \\
\hline
\end{tabular}

Note: the two set of results all reflect the same group of diabase samples.

Table 2 Physical and mechanical parameters of the intact rock * data in Table 2, minimum $\sim$ maximum / average

\begin{tabular}{|c|c|c|c|c|c|c|c|c|}
\hline \multirow[t]{2}{*}{ Petrology } & \multirow{2}{*}{$\begin{array}{c}\text { Dry } \\
\text { density } \\
\rho_{\mathrm{d}} \mathrm{g} / \mathrm{cm}^{3}\end{array}$} & \multirow{2}{*}{$\begin{array}{c}\text { Specific } \\
\text { gravity } \\
G_{\mathrm{s}}\end{array}$} & \multicolumn{2}{|c|}{ Compressive strength } & \multicolumn{2}{|c|}{ Tensile strength } & \multirow{2}{*}{$\begin{array}{c}\text { Elastic } \\
\text { modulus } E \\
\text { GPa }\end{array}$} & \multirow{2}{*}{$\begin{array}{c}\text { Poisson's } \\
\text { ratio } \mu\end{array}$} \\
\hline & & & $\begin{array}{c}\text { Dry } R_{\mathrm{d}} \\
\mathrm{MPa}\end{array}$ & $\begin{array}{c}\text { Wet } R_{\mathrm{w}} \\
\mathrm{MPa}\end{array}$ & $\begin{array}{c}\text { Dry } \sigma_{\mathrm{td}} \\
\mathrm{MPa}\end{array}$ & $\begin{array}{c}\text { Wet } \sigma_{\mathrm{tw}} \\
\mathrm{MPa}\end{array}$ & & \\
\hline \multirow[t]{2}{*}{ Tuff } & 2.31 & 2.57 & $\underline{50.3 \sim 75.5}$ & $\underline{36.4 \sim 59.7}$ & $\underline{7.10 \sim 14.0}$ & $\underline{5.00 \sim 9.98}$ & $\underline{22.0 \sim 30.5}$ & 0.25 \\
\hline & & & 66.0 & 47.3 & 10.4 & 6.98 & 26.2 & \\
\hline \multirow[t]{2}{*}{ Diabase } & 2.74 & 2.88 & $\underline{77.8 \sim 90.0}$ & $\underline{59.2 \sim 73.5}$ & $\underline{8.89 \sim 11.5}$ & $\underline{5.20 \sim 6.44}$ & $\underline{33.0 \sim 37.0}$ & 0.24 \\
\hline & & & 84.8 & 66.2 & 10.2 & 5.86 & 35.2 & \\
\hline
\end{tabular}

(Fig.2). According to the available records before 1997 when the collapse occurred and the field surveys and laboratory tests completed, it is known that the surrounding rocks in Biyutan cavern group had a massive and block structure (Gu, 1979; Wang et al., 1984), and the strata dipped westward. So, apparently, the engineering geological conditions were, overall, excellent.

\section{Mining operations}

Based on our observations on the existing extractive sites, the extraction methods used in Changyu Dongtian are of three types: surface quarrying, semi-surface quarrying, and underground mining. The Biyutan cavern group belongs to the last category. This may be due to the fact that, if the ancient miners first adopted surface quarrying, they would have to move the thick Quaternary overburden. Therefore the process of mining they employed was as follows. Firstly,

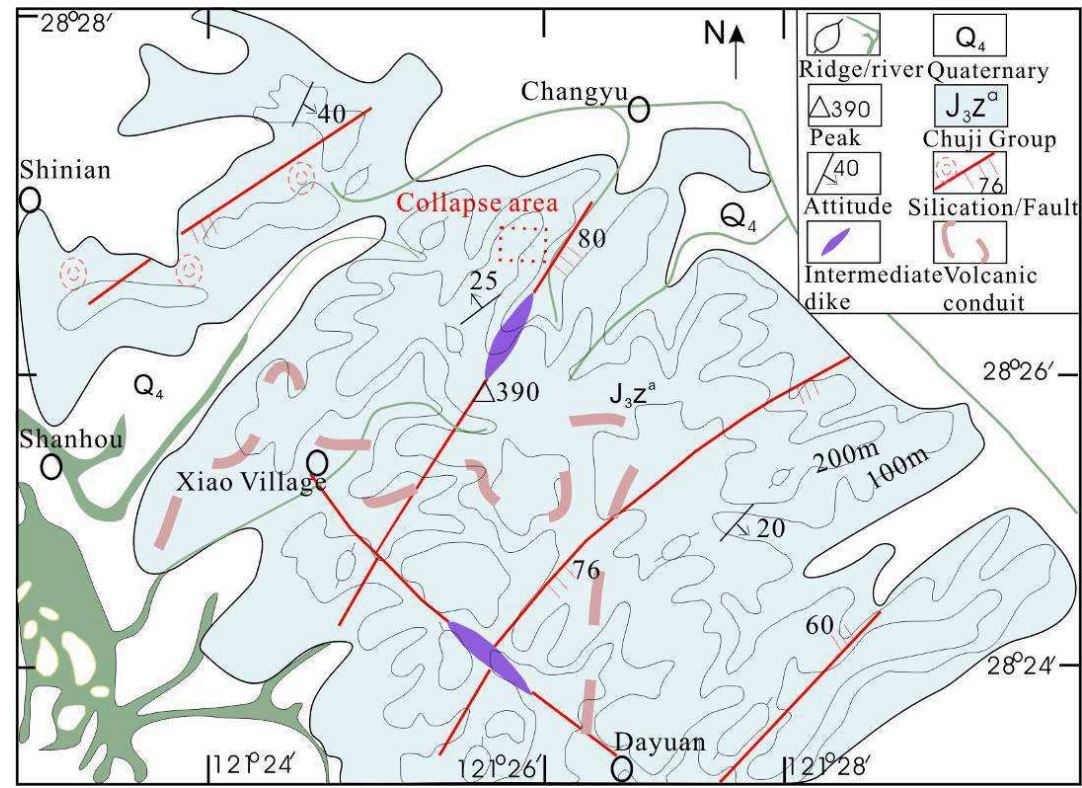

Fig.2 Geological conditions of the mining induced collapse area at Changyu Dongtian (According to the Regional Geological Survey Team of Zhejiang Province, 1978) a nearly horizontal adit was excavated; then stone was excavated from top to bottom to form a vertical bell-shaped cavern; another horizontal adit was then advanced beneath the previous one. Following these procedures, a huge group of caverns was finally formed. The heights of the caverns mainly range between $30 \mathrm{~m} \sim 40 \mathrm{~m}$, with the maximum of $60 \mathrm{~m}$, and in many cases, nearly $20 \mathrm{~m} \sim 40 \mathrm{~m}$ of the $30 \mathrm{~m} \sim 40 \mathrm{~m}$ are submerged in water (Fig.1a). Surface water flows into the cavern, gathered together and becomes pools that were regarded as a set of "green jade sinks" (Biyutan in Chinese).

On August 10, 1997, in order to get more stone, the miners extrcated several rock pillars that had been retained in the cavern using drilling and blasting method at 5:00 6:00 pm. The next morning, when the workers went back to the mine, they found that the caverns had collapsed. It should be mentioned that in July, 2001, the Wenling Tourist Administration Bureau had launched a tourism program focusing on the area that collapsed to remind people of the disasters that can arise from over extraction of stone. A tourist trail had already been completed.

\section{Collapse hazard}

According to the surveys of the remains, the collapsed Biyutan cavern group interviews with the mine technical directors, and the seismic records of the collapse (compliments of Zhejiang Seismological Bureau), it is established that at 7:01 am, August 11, 1997, Biyutan cavern group collapsed as a whole and the process lasted for about 20 40s. The south boundary of the massif fell along a fault, the strike of which was nearly EW. The falling blocks were as large as one hundred meters. There were 9 people inside the cavern, all of whom were killed by falling rocks. Water in the sinks (pools) was rapidly and suddenly squeezed and sprayed out of the cavern, casting rocks tens of meters in diameter into the air. Strong airflow and a shock wave formed immediately outside the cavern, mingled with the water flow. This firstly passed the minor ravine separating the two groups of Biyutan (at 
south) and Shuiyundong (at north), and hit the north cliff in which the Shuiyundong cavern group had been excavated. After that, it flowed downward past the opening of the Shuiyundong cavern group scenic area, breaking off all the trees on the way. Three people (miners) walking at the gate were hit by the shock wave and found dead in the Shichuangou gully (Fig.1b, Fig.4). In addition, a house in the present emergency evacuation position was hit by rolling rocks and an elderly woman was buried. Therefore, the collapse hazard results in a total of 13 deaths totally.

Also, four stone houses including two one-story power generation buildings, and two three-story residential buildings, constructed beside of the $3.6 \mathrm{~m}$ wide road connecting the entrance of Changyu Dongtian and the gate of the Shuiyundong cavern group scenic area were completely destroyed by the rush of water (Fig.1b). The south end of the $25 \mathrm{~m}$-long group of buildings nearest to the gate of Shuiyundong
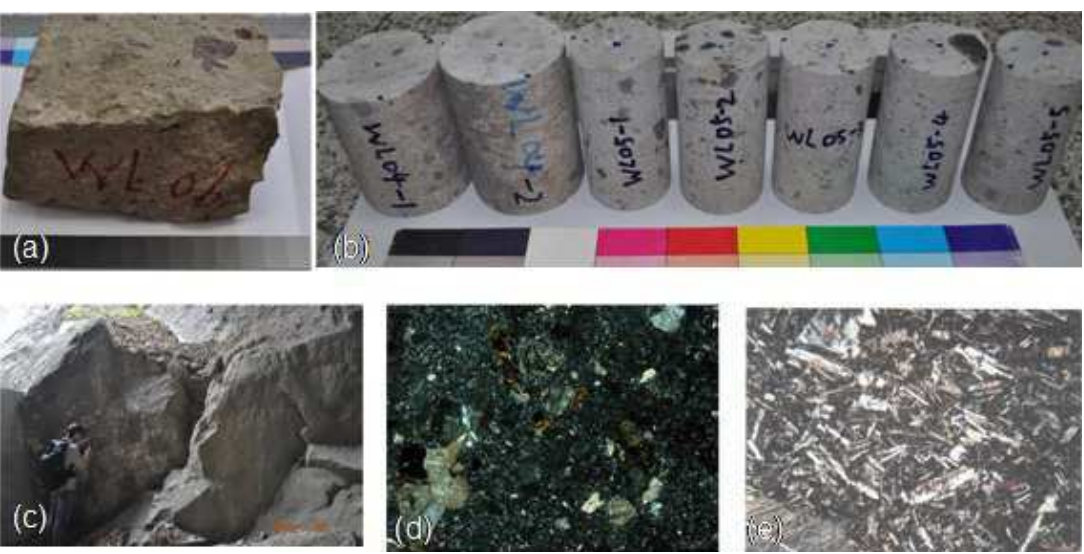

Fig.3. Structure images of the rocks in the mining induced collapse area. (a) the macro massive structure of tuff; (b) Cylinder samples of the massive tuff for mechanical tests; (c) layered diabase dyke contained in tuff; (d) microscopic image of tuff (orthogonal polarization); (e) microscopic image of diabase (orthogonal polarization)(sample CY-1). cavern group scenic area is $81 \mathrm{~m}$ away from a parking area to the north of the gate. Moreover, a Honda heavy motorcycle parked $151 \mathrm{~m}$ away from the north end of the stone houses was directly swept away by the airflow into the Shichuangou gully. Therefore this collapse had caused heavy losses to lives and property.

According to the mass and moving distance of the object, the power $W$ that the shock wave exerted on the object can be back calculated. With the velocity known, the kinetic energy $E$ of the moving object can be calculated. The relevant formulae are

$$
\begin{gathered}
W=F \cdot S \\
E=1 / 2\left(m v^{2}\right)
\end{gathered}
$$

Assuming the mass of the tractor $m$ is $1000 \mathrm{~kg}$, the lateral movement $S$ is precisely $1 m$, and the friction coefficient is 0.3 , the power $W_{t}$ on the tractor is:

$$
W_{t}=3000 \mathrm{~J}
$$

Besides, according to the Chinese National standard (GB67222011), the allowable vibration velocity for an ordinary house is $v=1 \mathrm{~cm} / \mathrm{s}$. Considering that four houses were completely destroyed,

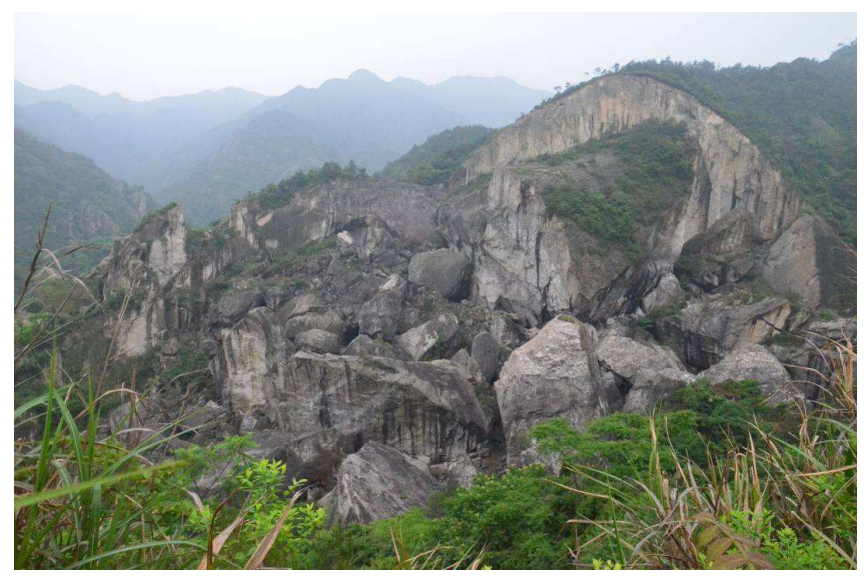

Fig. 4. The scene of the collapse area in Changyu Dongtian (Shooting direction: SE, standpoint: at hill above the Shuiyundong, Date: 16-10-2013). The SN striking Shichuan gully is at the left side. $v$ takes $1 \mathrm{~m} / \mathrm{s}$ here. The mass of the house is $10000 \mathrm{~kg}$, so the kinetic energy of the house $E_{h}$ is:

$$
E_{h}=5000 \mathrm{~J}
$$

Supposing the mass of the Honda heavy motorcycle is $200 \mathrm{~kg}$, and its moving velocity is $10 \mathrm{~m} / \mathrm{s}$, the kinetic energy of the motorcycle $E_{m}$ is:

$$
E_{m}=10000 \mathrm{~J}
$$

According to the equations (3) (5), at the location $80 \mathrm{~m}$ away from the quarry collapse site, the energy released by the shock wave was much greater than $18000 \mathrm{~J}$. It destroyed houses, moved tractor and motorcycle, indicating tremendous kinetic energy.

\section{Seismic records}

\section{Seismic record curves}

Some researchers (e.g. Hasegawa, 1989) proposed that due to the effects of gravity, regional stress and slope stress, the area above the mine goaf tends to form normal faults while the area below goaf is prone to form thrust faults which could slide along both joints and
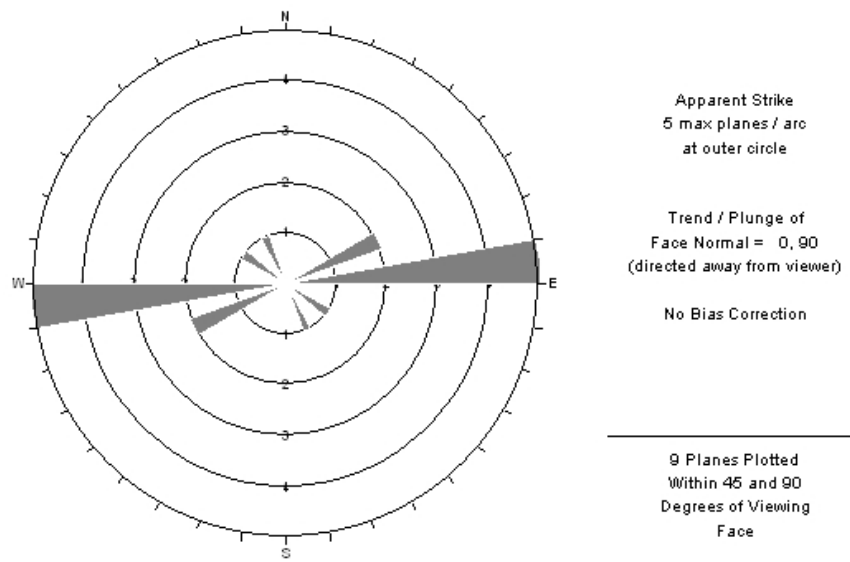

Fig. 5 Rose diagram of the strikes of structural discontinuities at the collapse area 
Table 3. The 3 site characters and recording seismic parameters

\begin{tabular}{|c|c|c|c|c|c|c|c|c|c|c|c|c|}
\hline $\begin{array}{l}\text { Seismic } \\
\text { station }\end{array}$ & $\begin{array}{l}\text { Latitude } \\
\text { North }\end{array}$ & $\begin{array}{c}\text { Longitude } \\
\text { East }\end{array}$ & $\begin{array}{c}\text { Elevation } \\
\text { above sea } \\
\text { level } / \mathrm{m}\end{array}$ & $\begin{array}{c}\text { Basement } \\
\text { rock }\end{array}$ & $\begin{array}{c}\text { Epicentral } \\
\text { distance } \\
/ \mathrm{km}\end{array}$ & Mag-N & Mag-E & $\begin{array}{c}\text { Max } \\
\text { amplitude } \\
\text { N-S/mm }\end{array}$ & $\begin{array}{c}\text { Max } \\
\text { amplitude } \\
\text { E-W/mm }\end{array}$ & $\mathrm{R}(\Delta)$ & $\begin{array}{l}\lg A \mu \\
(\mu \mathrm{m})\end{array}$ & $\mathrm{M}_{\mathrm{L}}$ \\
\hline Wenzhou & $27^{\circ} 55^{\prime}$ & $120^{\circ} 39^{\prime}$ & 20 & Granite & 93 & $2.97 \times 10^{4}$ & $1.85 \times 10^{4}$ & 3.5 & 2.1 & 3.4 & 0.1157 & 2.46 \\
\hline Ningbo & $29^{\circ} 58^{\prime}$ & $121^{\circ} 31^{\prime}$ & 20 & Tuff & 172 & $1.54 \times 10^{4}$ & $1.46 \times 10^{4}$ & 2.0 & 1.5 & 3.8 & 0.1163 & 2.87 \\
\hline Xin'anjiang & $29^{\circ} 29^{\prime}$ & $119^{\circ} 16^{\prime}$ & 90 & Sandstone & 240 & $2.38 \times 10^{4}$ & $2.46 \times 10^{4}$ & 1.0 & 2.5 & 4.1 & 0.0718 & 2.96 \\
\hline
\end{tabular}

bedding planes. Therefore, where joints have flexible striking that could be deemed a result of the rock mass sliding along multiple fractures (Yang et al., 1993).

As shown in Fig.1a, Wenzhou seismic station (WEZ) lies 93 km south to the collapse area, Biyuntan (BYT). It is built of granite, its geographical coordinate is $\mathrm{E} 120.67^{\circ}$ and $\mathrm{N} 27.93^{\circ}$, and its elevation above sea level is $20 \mathrm{~m}$. It recorded the seismic event, i.e., the ceiling collapse of the Biyutan cavern group (Fig.6). Meanwhile, Ningbo seismic station (NIB) lying to the northeast and $172 \mathrm{~km}$ far from $\mathrm{BYT}$, and Xin'anjiang seismic station (XAJ) lying to the northwest and $240 \mathrm{~km}$ far from BYT, also recorded the collapse event (Table 3). The instrument used in the three stations is the DD-1 short period (intrinsic cycle $T_{0}=1.0 \mathrm{~s}$ ) analog seismograph, which is widely used in Zhejiang Province at that time (Qiu, 1994; Lin, 2001).

Richter (1935) defined the instrumental local event magnitude scale as

$$
M_{L}=\lg A-\lg A_{0}(\Delta)
$$

Where, $M_{L}$ is the local event magnitude, also called Richter scale. $A$ is the maximum amplitude in seismic record, which is a mean value of the two horizontal components, mm. $A_{0}(\Delta)$ is the calibration function of epicentral distance, meaning the logarithmic value of the amplitudes at different epicentral distances on the 0.0 Richter scale.

$\mathrm{Li}$ (1958) modified the equation (6) to equation (7), which connects with short and long period seismographs commonly used in China.

$$
M_{L}=\lg A \mu+R(\Delta)
$$

Here, $A \mu$ is the maximum displacement of ground motion, which is defined as the mean values of the maximum amplitudes of the two horizontal components (N-S and E-W) of displacements of ground

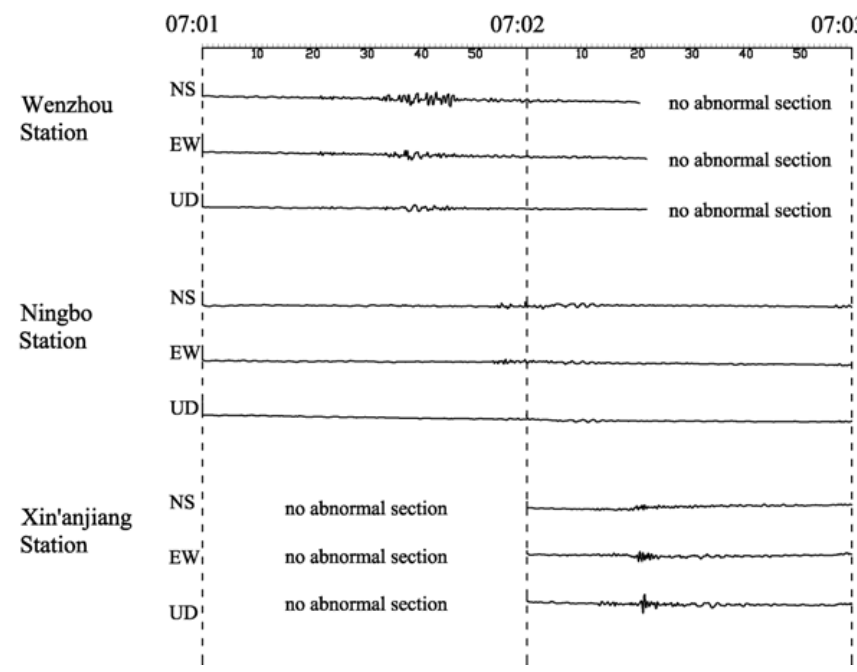

Fig. 6. Seismic spectrum curves of Changyu Dongtian collapse earthquake recorded at the 3 stations in the morning of August 11, 1997 motion, $\mu \mathrm{m} . R(\Delta)$ is a calibration function, the physical meaning of which is the compensation of seismic wave attenuation with distance. $\Delta$ is the epicentral distance, $\mathrm{km}$.

Records reflect that collapse earthquake as characteristically greatly affected by geological media and have an uncommon high frequency wave, well developed surface wave with short duration, and fast attenuation with distance. The parameter values from seismic records and calculation results from equations (6) and (7) are listed in Table 3. The mean value of the Richter scale from the three seismic record stations is $M_{L}=2.76$. Meanwhile, from the amplitude and duration time (Bormann, 2012), it is inferred that the $M_{L}$ is also about 2.8.

Compared with other seismic records of collapse earthquakes, that of the Changyu Dongtian event is relatively simple in waveform, with a small amplitude and low frequency. The shear wave $S$ is seldom observed, and the compression wave $P$ is faint. Wenzhou station records show that the weak $P$ wave in the up-down direction arrived at 7:01:20, and that the near-field $S$ wave in north-south direction arrived at 7:01:30.7. The maximum amplitude was 1.5 1.8 (relative unit in Fig.6). The amplification factors of the DD-1 seismograph in $N, E$ and $Z$ direction of the WEZ are $2.97 \times 10^{4}, 1.85 \times 10^{4}$ and $1.27 \times 10^{4}$, respectively (dimensionless, Table 3 ). It can be roughly estimated from Fig. 6 that the epicenter (the collapse area) is the mine collapse induced earthquake from the three seismic stations (the distance is calculated by the GPS coordinates). Compared with other collapse earthquakes the seismic waves which are of large amplitudes and rich in waveforms, this earthquake was characterized by low energy and short duration (Table 4).

\section{Energy conversion in collapse}

It was reported that during the 10 hours from the evening when the supporting pillars were excavated to the next morning when the collapse occurred, the surrounding rock masses especially those at

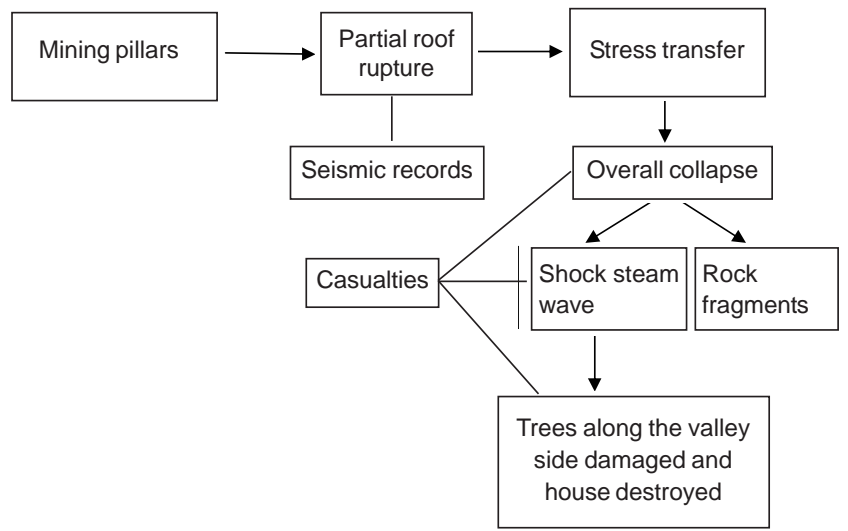

Fig. 7. Procedure schematic of mining induced collapse and disasters at Biyuntan cavern group 
Table 4 Comparison of characteristics of collapse earthquakes in six different regions of China

\begin{tabular}{|c|c|c|c|c|c|c|}
\hline $\begin{array}{l}\text { Collapse events at } \\
\text { different regions }\end{array}$ & Body wave & Surface wave & Amplitude & Wave form & $\begin{array}{l}P \text {-wave first } \\
\text { motion direction }\end{array}$ & Ref. \\
\hline $\begin{array}{l}\text { Seismic phase analysis } \\
\text { of four collapse } \\
\text { earthquakes in a } \\
\text { center-south network } \\
\text { of Shandong Province }\end{array}$ & $\begin{array}{l}\text { The direct wave } P \text { and } \\
S \text { have large cycle. The } \\
\text { cycle of the body wave } \\
\text { band is generally } 0.2-\text { - } \\
0.5 \mathrm{~s} \text { waveform is } \\
\text { simple and neat, contain } \\
\text { little of the high- } \\
\text { frequency component }\end{array}$ & $\begin{array}{l}\text { There are obvious short } \\
\text { cycle surface waves in } \\
\text { seismic wave column, } \\
\text { and surface wave cycle } \\
\text { is generally within } \\
0.5-1.6 \mathrm{~s} \text {, waveform } \\
\text { develop, and has obvious } \\
\text { frequency dispersion } \\
\text { characteristics }\end{array}$ & $\begin{array}{l}\text { The amplitude } \\
\text { attenuates fast, } \\
\text { and the duration } \\
\text { time of seismic } \\
\text { wave is } 10-15 \mathrm{~s} \\
\left(\mathrm{M}_{\mathrm{L}} 2.6-3.2 \text {, }\right. \\
\text { double amplitude } \\
\text { is } 4 \mathrm{~mm})\end{array}$ & $\begin{array}{l}\text { Waveform has a } \\
\text { large head feature } \\
\text { in the network } \\
\text { records }\end{array}$ & $\begin{array}{l}\text { Records near the } \\
\text { earthquake source } \\
\text { show the direction } \\
\text { of the } P \text {-wave first } \\
\text { motion is pointed } \\
\text { towards the } \\
\text { earthquake } \\
\text { source }\end{array}$ & $\begin{array}{l}\text { Lin et al., } \\
1990\end{array}$ \\
\hline $\begin{array}{l}\text { Waveform of the } \\
\text { collapse earthquake } \\
M_{L} 3.9 \text { on August 10, } \\
2008 \text { at Shenmu, } \\
\text { Shan'anxi Province }\end{array}$ & $\begin{array}{l}S \text {-wave is more obvious, } \\
\text { its cycle is larger, and } \\
\text { has no significant } \\
\text { difference with the } \\
\text { cycle of surface wave }\end{array}$ & $\begin{array}{l}\text { whether the epicenter } \\
\text { distance is large or not, } \\
\text { the surface wave appears, } \\
\text { then it develops and } \\
\text { its cycle is larger }\end{array}$ & & $\begin{array}{l}\text { The high frequency } \\
\text { components are a } \\
\text { bit low. The wave } \\
\text { form looks smooth. }\end{array}$ & & $\begin{array}{l}\text { Di et al., } \\
2009\end{array}$ \\
\hline $\begin{array}{l}\text { The seismic phase } \\
\text { analysis of collapse } \\
\text { earthquake happened } \\
\text { in junction of Anhui } \\
\text { and Zhejiang, } \\
\text { Dingyuan, Huaibei, } \\
\text { Huainan, and south } \\
\text { Shandong }\end{array}$ & $\begin{array}{l}\text { High-frequency } \\
\text { components are } \\
\text { absorbed, the body wave } \\
\text { has larger cycle than } \\
\text { the natural earthquake, } \\
\text { the speed-type cycle is } \\
\text { generally } 0.02 \text { s to } 1.6 \mathrm{~Hz} \text {. } \\
\text { Shear wave is not } \\
\text { developed }\end{array}$ & $\begin{array}{l}\text { There are obvious short } \\
\text { cycle surface waves called } \\
R g \text { wave in seismic wave } \\
\text { column. The speed-type } \\
\text { cycle is generally } 0.1 \mathrm{~s} \\
\text { to } 0.2 \mathrm{~Hz} \text { in the surface } \\
\text { wave. Waveform develop, } \\
\text { and has obvious positive } \\
\text { dispersion characteristics, } \\
\text { namely high cycles at } \\
\text { first, small cycles } \\
\text { afterwards }\end{array}$ & $\begin{array}{l}\text { The amplitude } \\
\text { attenuates fast, } \\
\text { and the duration } \\
\text { time of seismic } \\
\text { wave is shorter } \\
\text { than the compar- } \\
\text { able natural } \\
\text { earthquakes }\end{array}$ & $\begin{array}{l}\text { Waveform of the } \\
\text { whole band is } \\
\text { simple and neat } \\
\text { contain very little } \\
\text { high-frequency } \\
\text { component. In } \\
\text { the records, the } \\
\text { body wave has a } \\
\text { small head feature. }\end{array}$ & & $\begin{array}{l}\text { Wang et } \\
\text { al., } 2012\end{array}$ \\
\hline $\begin{array}{l}\text { The collapse earth- } \\
\text { quake } M_{L} 2.2 \text { at 1:56 } \\
\text { on April } 14,1987 \text { in } \\
\text { Yanmen village, } \\
\text { Baisha Town, } \\
\text { Yangshuo County }\end{array}$ & $\begin{array}{l}\text { Cycle compared to } \\
\text { tectonic earthquakes } \\
\text { on the same level and } \\
\text { the same epicenter } \\
\text { distance is about } \\
0.25 \text { larger. }\end{array}$ & & $\begin{array}{l}\text { The amplitude of } P \\
\text { and } S \text { is relatively } \\
\text { larger, As /Ap>10 }\end{array}$ & & & $\begin{array}{l}\text { Yao, } \\
1989\end{array}$ \\
\hline $\begin{array}{l}\text { At 7:01 on August 11, } \\
1997 \text { Changyu } \\
\text { collapse earthquake }\end{array}$ & $\begin{array}{l}\text { Body wave signals are } \\
\text { not developed, small } \\
\text { amplitude }\end{array}$ & $\begin{array}{l}\text { Surface wave growth } \\
\text { but its frequency is low } \\
\text { and amplitudes are small }\end{array}$ & $\begin{array}{l}\text { Shear wave } S \\
\text { does not develop }\end{array}$ & $\begin{array}{l}\text { The direction of } \\
U \text { is down when } \\
P \text {-wave first } \\
\text { motions }\end{array}$ & & $\begin{array}{l}\text { This } \\
\text { paper }\end{array}$ \\
\hline
\end{tabular}

cavern roof, had experienced local instability and stress redistribution, which finally leaded to the overall collapse (Fig.7).

Therefore excessive extrcation of pillars had triggered a major roof collapse which, in turn, gave rise to a collapse earthquake that was recorded by the three nearby seismic stations. According to the post-earthquake damage evaluation, the seismic Mercalli intensity reached III, and the magnitude was recorded at $\mathrm{M}_{\mathrm{L}}=2.8$. Based on the common measurement that earthquake at magnitude 1.0 releases an energy of $2 \times 10^{13} \mathrm{erg}\left(2 \times 10^{6} \mathrm{~J}\right)$, and that at magnitude 2.0 releases an energy of $6.3 \times 10^{14} \mathrm{erg}\left(6.3 \times 10^{7} \mathrm{~J}\right)$, the energy produced in this collapse earthquake is roughly estimated $6.12 \times 10^{6} \mathrm{~J}$. If we suppose that the water spraying from the cave weighed about $20000 \mathrm{~kg}$ and had a velocity of $15 \mathrm{~m} / \mathrm{s}$, the energy consumed against the potential energy of water is $4.5 \times 10^{6} \mathrm{~J}$. According to equations (3) (5), at the location $80 \mathrm{~m}$ away from the collapse site, the energy released by the shock wave was more than $1.8 \times 10^{4} \mathrm{~J}$.

\section{Lessons from this mining induced collapse disaster}

After the catastrophic roof failure of Biyutan cavern group, Changyu Dongtian was developed as a scenic area in order to get rid of the risk that another collapse event might occur because of excessive excavation of supporting pillars. But some experiences obtained from 
this event are applicable to other mines in terms of disaster prevention: (1) do not adopting risky mining behavior, e.g., excavating supporting pillars; (2) installing complete systems to monitor the deformation and acoustic emission at key positions so as to make mining procedures flexible when necessary; (3) timely evacuation of people nearby if a large scale collapse seems likely to occur, and hence minimizing loss of lives and property.

\section{Conclusions}

The large scale roof collapse at Changyu Dongtian quarry in August 11, 1997 was a major failure triggered by local instability caused by excessive excavation of supporting pillars. The seismic waves produced by this collapse earthquake were fortunately recorded by the three seismic stations as the Wenzhou $93 \mathrm{~km}$ to the south, Ningbo $172 \mathrm{~km}$ to the northeast and Xin' anjiang $240 \mathrm{~km}$ to the northwest. The recorded waves mainly comprised low frequency and small amplitude surface waves with no evident body waves. This shallow collapse earthquake was therefore propagated mainly in the form of surface waves and the area of influence was comparatively small.

According to the seismic records, the collapse earthquake magnitude is roughly estimated at $\mathrm{M}_{\mathrm{L}}=2.8$, and the seismic intensity was inferred to be III based on field observations of the damage. The seismic energy was mainly transformed as potential energy of water and kinetic energy of objects impacted by the shock wave. There were 13 people killed and several houses destroyed within $150 \mathrm{~m}$. Experiences obtained from this case study therefore are relevant to the prevention of roof collapse disasters in mining industry.

\section{Acknowledgements}

Seismic records were provided by Zhejiang Seismological Bureau. Prof. Miaoyue Wang helped greatly in explaining the seismic records. During the site investigation, we had sincere and professional help from Mr. Lin Yuqiu and other staff from the Changyu Dongtian Tourism Industrial Co., LTD, Wenzhou City. We appreciate financial support provided by the State Key Laboratory of Geohazard Prevention and Geoenvironment Protection (SKLGP2011K007), the Key Research Program of the Chinese Academy of Sciences (KZZDEW-05-02), and by the National Natural Science Foundation of China (NSFC) (Nos. 41372324, 41172269). We also appreciate the support from the Chinese Special Funds for Major State Basic Research Project under Grant No.2014CB046901. The editors of the Episodes kindly provide a great help making the English presentation more correct and fluent.

\section{References}

Alvarez-Garcia Isabel N., Ramos-Lopez Francisco L., Gonzalez-Nicieza Celestino, Alvarez- Fernandez M.Inmaculada, Alvarez-Vigil Arturo E., 2013, The mine collapse at Lo Tacón (Murcia, Spain), possible cause of the Torre Pacheco earthquake (2nd May 1998, SE Spain). Engineering Failure Analysis, v. 28, pp. 115-133.

Bormann, P., 2012, New Manual of Seismological Observatory Practice (NMSOP-2). IASPEI, GFZ German Research Centre for Geosciences.

Chen Yaohua, Zhu Jingying, 2012, World heritage perspective on stone culture landscape in Changyu Dongtian. Cultural Relics of Mining Industry, pp. 13-18.

DSS (Datong Seismic Station), 1974, Using seismic method exploring coal mine collapse rules. The Shanxi Earthquake Communication, v. (1), pp.14-16.
Di Xiuling, Wang Ping, Jin Zhaodi, Wang Jianchang, 2009, Preliminary analysis on collapse earthquakes in Northern Yulin, Shan' anxi Province. Journal of Catastrophology, v. 24(4), pp. 81-83.

Farahani J.V., Zare M., 2014, Site characterizations for the Tehran network (TDMMO) in Tehran region using micro-earthquake, microtremor and quarry blast data. Soil Dynamics and Earthquake Engineering, v. 63, pp. 235-247.

Gu Chengzhi, 1982, The collapse earthquake at the Three Gorges of Yangtze River. Earthquake, v. 3, pp. 21-22.

Gu Dezhen, 1979, Engineering geomechanical basement of rock mass. Beijing: Science Press, 296 pp.

Hasegawa H.S., 1989, Induced seismicity in mines in CanadaNan overview. Seismicity in Mines, v. 129(3/4), pp.189-199.

He Xiuquan, Cao Jinliang, Xu Zhi, 1997, Study on the feature of collapse earthquake caused by coal mining and its forecast, Shanxi. The Chinese Journal of Geological Hazard and Control, v. 8 (Supl.), pp.108-113.

Hatzor Y.H., Talesnick M., Tsesarsky M., 2002, Continuous and discontinuous stability analysis of the bell-shaped caverns at Bet Guvrin, Israel. International Journal of Rock Mechanics and Mining Sciences, v. 39, pp. 867-886.

Hu Yuliang, Yang Qingyuan, Chen Xiancheng, 1998, Mining-induced earthquakes in the area around the Three Gorge Project. Seismology and Geology, v. 20(4), pp. 349-360.

Li Jinlong, Dong Changli, 2001, Explosion identification for digital seismic record. Seismological and Geomagnetic Observation and Research, v. 22(3), pp. 28-35.

Li Shanbang, 1958, Practical seismic magnitude tables. Journal of Geophysics, v. 7(2), pp. 98-102.

Lin Huaichun, Wang Baoping, Liu Hongrui, Jiang Jiukun, 1990, Comparative study of tectonic and collapse earthquakes. Acta Seismologica Sinica, v. $12(4)$, pp. $448-455$.

Lin Shengfa, 2001, The characteristic and analysis of regional earthquake recorded at Wenzhou Seismic Station. Seismological and Geomagnetic Observation and Research, v. 22(5), pp. 53-55.

Merad M.M., Verdel T., Roya B., Kouniali S., 2004, Use of multi-criteria decision-aids for risk zoning and management of large area subjected to mining-induced hazards. Tunnelling and Underground Space Technology, v. 19 , pp. $165-178$.

National Standard of PRC., 2010, Code for seismic design of buildings (GB50011-2010). Beijing: Chinese Building Industry Press.

National Standard of PRC., 2001, Seismic ground motion parameter zonation map of China (GB18306- 2001). Beijing: China Standard Press.

National standard of PRC., 2011, Safety regulations for blasting (GB67222011). Beijing: China Standard Press.

Qiu Yongping, 1994, The phase analysis of the regional-earthquakes recorded by the DD-1 seismograph in seismic station of Ningbo. Seismological and Geomagnetic Observation and Research, v. 15(1), pp. 45-50.

Regional Geological Survey Team of Zhejiang Province, 1978, Regional geological survey report (1:200,000, Xianju Sheet), 266pp.

Wang Sijing, Yang Zhifa, Liu Zhuhua, 1984, Analysis on surrounding rock stability for underground projects. Beijing: Science Press, 282pp.

Wang Guizhang, Ling Xueshu, Zhang Youlong, Xia Shi'an, Wu Hui, 2012, Characteristic recognition of non-natural earthquakes such as explosions in Anhui and the periphery. J. of Institute of Disaster-Prevention Science and Technology, v. 12(2), pp. 26-31.

Wenling Tourism Management Bureau, 2005, Explanation of the formation of Changyu Dongtian. Special issue of famous scenery Wenling. Journal of Famous Scenery, v. 5, pp. 68-71.

Yang Qingyuan, Chen Xiancheng, Ma Wentao, 1993, Formation mechanism of microearthquakes warm in Yanguan area on the Yangtze Gorges. Seismology and Geology, v. 15(3), pp. 247-252.

Yao Hong, 1989, Primary study on the 1987 Yangshuo collapse earthquake. Seismological and Geomagnetic Observation and Research, v. 5, pp. 5-7.

ZGMB (Zhejiang Geology and Mineral Bureau), 1989 Regional geology of Zhejiang Province. Beijing: Geological Publishing House, 688pp.

Zhang Lifen, Yao Yunsheng, Li Jinggang, Wu Haibo, 2013, Corner frequency characteristic of tectonic earthquakes and collapsed ones in Three Gorges region. Journal of Geodesy and Geodynamics, v. 33(2), pp. 27-40.

Zhao Yong, Liu Weihong, Gao Yanlin, 1995, Distinguishing earthquake, explosion and mine earthquake in Beijing area. Seismological and Geomagnetic Observation and Research, v. 16(4), pp. 48-54. 